\section{Huseyin Ibrahim Adali}

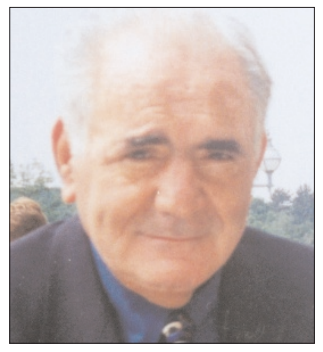

Huseyin Adali passed away suddenly but peacefully, with his family at his side, on 16th March 2002, aged 69. He closed his eyes to the world after becoming calmly aware of a progressive brainstem haemorrhage.

A Turkish Cypriot, H. Adali was born in Malya, a small farming village in Limasol in undivided Cyprus. Having paid his way through the University of Istanbul Dental Faculty by working at the Cypriot Customs Office, he graduated in 1958 and established a rapidly growing practice in Limasol. After moving to Germany to study removable prosthodontics, he returned to Cyprus but the impending conflict in Cyprus persuaded H. Adali amongst many to leave their homes and resettle in London. Passing the Edinburgh Statutory Examinations allowed him to open the doors of his dental surgery in Haringey, North London, to serve the local community. His typical integrity, skill, meticulous attention to detail and calm sympathetic approach to problems drew many to him. Many of his patients from Limasol located him in London and remained loyal for over 35 years. The practice flourished serving the multicultural patient base.

He closely followed developments in dental material research, reinventing his own practising methods throughout his career. $\mathrm{H}$. Adali maintained his hand in technical dental materials by providing his own crown and bridgework from his onsite laboratory. He avidly studied the progress of dental implants from the conceptual stage early in his career to their current place in dental practice.

\section{John H. Mercieca}

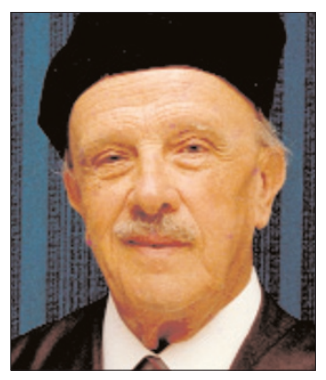

The dental profession in Malta lost its doyen with the death of John $\mathrm{H}$. Mercieca on 22 February 2003.

He was born in 1912 and dedicated a large part of his long life to dentistry. He joined in the first Course of Dental Surgery at the then Royal University of Malta and graduated in 1937. He went into private practice where he spent all his working life except for the war years when he was appointed a Surgeon Captain in the RADC, serving under Majors Victor Vella-Grech and D.V.Taylor.

\section{His love of dentistry and forceful} personality led him to play a fundamental role in the development and history of the Dental Association of Malta. He was appointed President, a position he held for 20 years until 1981 when he was made Honorary Life President.
He closely followed developments in dental material research, reinventing his own practising methods throughout his career... He avidly studied the progress of dental implants from the conceptual stage early in his career to their current place in dental practice.

In 1975, a young lady whom he first saw from a photograph belonging to an acquaintance became Mrs Adali and later shared the running of the dental practice in London. Their son went on to graduate as a doctor from the Royal Free Hospital and daughter to graduate as a dentist from Guy's Hospital.

$\mathrm{H}$. Adali was always pursuing new challenges in both his working life and leisure. He took upon seemingly impossible DIY feats in the house, and enjoyed languages, wine making, beekeeping, sailing, entertaining and the infamous kebab carving episodes. He was a founding member of the London Turkish Radio and Turkish Centre Trust, which raised funds towards care centres in Famagusta, North Cyprus. He was also passionately devoted to current political and environmental issues. H. Adali will be most remembered for his kind, modest character and equable temperament and nature generous to a fault. His wife, children, and friends old and new dearly miss Mr H I Adali.

Nazan Adali

His love of dentistry and forceful personality led him to play a fundamental role in the development and history of the Dental Association of Malta. He served as Hon. Secretary from 1947 to 1961 when he was appointed President, a position he held for 20 years until 1981 when he was made Hon. Life President. He was one of the representatives of the dental profession on the Malta General Medical Council from its inception in 1959 and served continuously for forty years. He was an examiner in Dental Surgery at the University of Malta as well as a member of the Faculty for many years. In 1987 John Mercieca, together with Arthur Prophet, were awarded the D.Sc. (Honoris Causa) of the University of Malta.

Besides his family, he had two other main activities. He was an accomplished linguist, and often acted as a court interpreter for German and Russian nationals and was a renowned philatelist with an encyclopedic knowledge of stamps. He was the mainspring behind the Malta Philatelic Society which also appointed him an Honorary Life President. His contribution to Maltese Society was acknowledged when in 1993 he was decorated with the M.O.M. (Medal of Merit) by the State of Malta. His honesty and reliability served the dental profession well and he was respected and loved by all his colleagues. He will be remembered by many British dental surgeons visiting Malta. The death of his beloved Mary was a severe blow from which he never fully recovered. He is survived by his son Arthur and daughter-in-law Ruby who devotedly looked after him and his beloved grandchildren. 